\title{
Towards a pragmatic definition of cell type
}

Tiago Lubiana ${ }^{1}$ and Helder I Nakaya ${ }^{1}$

${ }^{1}$ Affiliation not available

January 4, 2021

\section{Hosted file}

technotype_to_authorea.pdf available at https://authorea.com/users/384178/articles/501068towards-a-pragmatic-definition-of-cell-type 